\title{
Apoptosis in the transplanted canine transmissible venereal tumor during growth and regression phases
}

\author{
[Apoptose no tumor venéreo transmissivel canino durante as fases de crescimento e regressão] \\ F.G.A. Santos, A.C. Vasconcelos, J.E.S. Nunes, G.D. Cassali, T.A. Paixão, \\ A.S. Martins, S.S. Silva, R.F. Martins, L. Moro* \\ Instituto de Ciências Biológicas - UFMG \\ Caixa Postal 486 \\ 31270-901 - Belo Horizonte, MG
}

\begin{abstract}
Twelve male, mongrel, adult dogs were subcutaneously transplanted with cells originated from two canine transmissible venereal tumors (TVT). The aim was to demonstrate and to quantify the occurrence of apoptosis in the TVT regression. After six months of transplantation, a tumor sample was obtained from each dog, being six dogs with TVT in the growing phase and six in the regression phase as verified by daily measurements. Samples were processed for histological and ultrastructural purposes as well as for DNA extraction. Sections of $4 \mu \mathrm{m}$ were stained by HE, Shorr, methyl green pyronine, Van Gieson, TUNEL reaction and immunostained for P53. The Shorr stained sections went through morphometry that demonstrated an increase of the apoptotic cells per field in the regressive tumors. It was also confirmed by transmission electron microscopy, which showed cells with typical morphology of apoptosis and by the TUNEL reaction that detected in situ the $3{ }^{\prime} \mathrm{OH}$ nick end labeling mainly in the regressive tumors. The regressive TVTs also showed an intensified immunostaining for P53 besides a more intense genomic DNA fragmentation detected by the agarose gel electrophoresis. In conclusion, apoptosis has an important role in the regression of the experimental TVT in a way that is P53-dependent.
\end{abstract}

Keywords: dog, venereal tumor, apoptosis, cell death

\section{RESUMO}

Doze cães, adultos, machos e sem raça definida foram transplantados subcutaneamente, na região hipogástrica, com células originadas de dois tumores venéreos transmissíveis caninos (TVT). O objetivo do estudo foi demonstrar e quantificar a ocorrência de apoptose na regressão do TVT. Após seis meses, foi obtido um tumor de cada animal, totalizando seis em crescimento e seis em regressão. Fragmentos dos tumores foram processados para avaliação histológica, ultra-estrutural e também para extração de $D N A$. Cortes de 4 um foram corados em HE, Shorr, verde de metila pironina e Van Gieson e alguns foram submetidos à reação do TUNEL e à imunoistoquímica para P53. Secções coradas pelo Shorr, submetidas à morfometria, demonstram maior índice apoptótico nos tumores em regressão. Esse achado foi confirmado pela microscopia eletrônica de transmissão que evidenciou células com morfologia típica de apoptose e pela reação de TUNEL que marcou mais células nos tumores em regressão que naqueles em crescimento. A imunomarcação para P53 foi mais intensa nos tumores em regressão, assim como a fragmentação internucleossômica do genoma mostrada pela eletroforese em gel de agarose. Concluiu-se que a apoptose tem importante papel na regressão do TVT transplantado experimentalmente, sendo, nesse caso, dependente de P53 para a sua execução.

Palavras-chave: cão, tumor venéreo, apoptose, morte celular

Recebido em 21 de maio de 2007

Aceito em 15 de abril de 2008

Corresponding author (autor para correspondência)

E-mail: moro@icb.ufmg.br 


\section{INTRODUCTION}

The canine transmissible venereal tumor (TVT) is a contagious neoplasm of round cells that first affects the external genitalia of adult dogs of both sexes. Experimentally, it may be transmitted by subcutaneous inoculation of integral and viable tumor cells in a susceptible host (Cohen, 1980; Chu et al., 2001). The TVT frequently regresses spontaneously in healthy, adult animals. The regression is associated with lymphocytes and plasma cells infiltration as well as necrosis (Cohen, 1978; Pérez et al., 1998) and apoptosis (Santos et al., 2001). Fibrosis may occur during the final stages of the regression (Stewart et al., 1959).

Apoptosis represents a mechanism of controlled cell deletion and plays an opposite role to mitosis (Kerr et al., 1972) regulating the animal cell population (Kerr, 1993). Apoptosis might be triggered or inhibited by pathological (Batista et al., 2005; Alves et al., 2006; Batista et al., 2007) and physiological environmental stimuli (Arends and Wyllie, 1991).

The aim this study was to characterize the morphological, immunohistochemical and biochemical aspects of apoptosis as a factor in TVT regression. Additionally, it was an attempt to establish TVT as a model in order to study tumor regression.

\section{MATERIALS AND METHODS}

The tumor cells were obtained from two mongrel, adult, male dogs presenting genital TVT of natural occurrence. TVT cells were transferred to 29 healthy, conventional, male, adult, mongrel dogs from a Center of Zoonosis. Animals were fed commercial food and water was given ad libitum. After six months, 12 dogs were selected: (1) six with growing tumors and (2) six with regressive tumors. All procedures with the animals were carried out in accordance to appropriate humane methods.

The tumor samples were minced mechanically, crushed on stainless steel mesh, washed with Ringer containing antibiotics (2000IU of penicillin $/ \mathrm{ml}$ and $20 \mathrm{mg}$ of streptomycin $/ \mathrm{ml}$ ), filtered and resuspended in Ringer. Each dog was inoculated with $10^{7}$ viable cells $/ \mathrm{ml}$, subcutaneously in the hypogastric region, in four different places, $10 \mathrm{~cm}$ apart from each other (Koike et al., 1979). The tumors were measured with calipers using the formula proposed by Liao et al. (2003) [length $\mathrm{x}$ width $\mathrm{x}$ height $\mathrm{x} \pi / 4\left(\mathrm{~cm}^{3}\right)$ ] to calculate the volume of the tumor.

Imprints were fixed in methanol and stained by May Grünwald-Giemsa (Luna, 1968) to confirm the TVT by cytology.

Fragments fixed with $2.5 \%$ glutaraldehyde in $0.1 \mathrm{M}$ phosphate buffer were post fixed in osmium tetroxide, dehydrated and embedded in Epon-Araldite 502. Ultrathin sections were counterstained with $2 \%$ uranyl acetate and lead cytrate and examined on a Zeiss EM $10^{1}$.

Tumor fragments were fixed in $10 \%$ buffered formalin, sectioned and processed according to routine techniques for paraffin inclusion. Sections of $4 \mu \mathrm{m}$ were submitted to TUNEL reaction, stained by $\mathrm{HE}$, Shorr ${ }^{2}$, methyl green pyronine (MGP) (Moffitt, 1994) and Van Gieson (Luna, 1968).

Slides stained by Shorr were scanned and the section areas were measured $\left(\mu \mathrm{m}^{2}\right)$. All morphometric data were generated with a digital image analyzer using specific software ${ }^{3}$.

Out of a group of 1000 cells the apoptotic cells were measured in tumor sections stained by Shorr and the apoptotic index (AI) was calculated.

The collagen fibers in each tumor phase were analyzed in sections stained by Van Gieson in the areas of greater concentration of collagen. The pixels of the collagen areas were selected and a binary image was created.

The TUNEL reaction was applied for the detection of the in situ genome fragmentation, by using a commercial kit Apoptag-peroxidase ${ }^{4}$. The reaction was carried out as described by the manufacturer. Briefly, slides were incubated with $30 \mu \mathrm{g} / \mathrm{ml}$ of proteinase $\mathrm{K}^{5}$ for 20 minutes and the endogenous peroxidase was quenched with $5 \%$

${ }^{1}$ Carl Zeiss, 7082 - Oberkochen, Germany

${ }^{2}$ Merck, Cat\#9275 - Darmstadt, Germany

${ }^{3}$ Kontron, KS 300 V 2.0 Zeiss - Köln, Germany

${ }^{4}$ Oncor - Gaithersburg, MD, USA

${ }^{5}$ Sigma - St. Louis, USA 
$\mathrm{H}_{2} \mathrm{O}_{2}$. Terminal deoxynucleotide transferase (TdT) and deoxynucleotides were applied and slides placed in a humid atmosphere at $37^{\circ} \mathrm{C}$ for $1.5 \mathrm{~h}$. The reaction was stopped by a blocking buffer; the sections were treated with peroxidase streptavidin conjugate plus diaminobenzidine (DAB) and counterstained with methyl green.

Sections were deparaffinized and hydrated and then treated with a retrieval solution ${ }^{6}$ at $100^{\circ} \mathrm{C}$. The endogenous peroxidase activity was quenched with $3 \% \mathrm{H}_{2} \mathrm{O}_{2}$ and the unspecific antibodies were blocked. The slides were incubated with the primary P53 antibody $(\mathrm{CM} 1)^{7}$ followed by incubation with the secondary antibodies (Biotiny Goat Anti-Polyvalent UltraVision Large Volume Detection System Anti-Polyvalent, HRP) ${ }^{8}$ in a humid chamber. Afterwards, the DAB peroxidase reagent was applied and the sections were counter stained with Harry's hematoxylin. Tumors with more than $5 \%$ positive labeled cells were considered positive.

Approximately $2 \mathrm{mg}$ of the tumor tissue were ground in $0.5 \mathrm{ml}$ of TTE lysis buffer $(10 \mathrm{mM}$ Tris; $0.25 \%$ Triton $\mathrm{x}-100 ; 1 \mathrm{mM}$ EDTA), spun at $500 \mathrm{x} \mathrm{g}$ for 10 minutes and the DNA was extracted from the supernatant by standard procedures (Sambrook et al., 1989). The DNA pattern was analyzed at the $1.5 \%$ agarose gel standard electrophoresis.

The experimental design was entirely randomized. The apoptotic index, the inflammatory infiltrate and fibrous areas were submitted to ANOVA and treatments were compared through Fisher's test and MannWhitney's test $(\mathrm{P}<0.05)$ (Sampaio, 1998).

\section{RESULTS}

Imprints of the transplanted and natural TVTs had round voluminous cells with epithelial pattern and round or oval nuclei. The nuclei had a unique, bulky, purplish and eccentric nucleolus. The cytoplasm was colorless or mild blue, granular and contained clear well defined vacuoles.

${ }^{6}$ DakoCytomation - Carpinteria, USA

${ }^{7}$ Novocastra Laboratories Ltd. - Newcastle, UK

${ }^{8}$ LabVision - Fremont, USA
The tumor cells were organized diffusely or in cords supported by a connective tissue. The stroma was minimal in the growing tumors and abundant in the regressive ones (Fig. 1A and 1B). The cells were large and round or polyhedral in shape and had scanty, poorly stained cytoplasm with indistinct boundaries. The nuclei were large and round, with either bulky and central or bulky and eccentric nucleoli. The chromatin was granular and marginal. The growing tumors presented a mild nodular subcapsular or perivascular inflammatory infiltrate. In the regressive tumors, a diffuse and evident subcapsular or a perivascular inflammatory infiltrate was observed. Both growing and regressive tumors were capsulated.

The TVT cells frequently showed apoptotic characteristics, such as: shrunk anoikic cells with condensed chromatin and fragmented nuclei (Fig. 2B).

The AI in the growing (Fig. 3A) tumors $(0.38 \pm 0.08)$ was smaller than in the regressive (Fig. 3B) tumors $(0.62 \pm 0.11)(\mathrm{P}<0.05 \%)$.

The tumors in the regression phase presented a greater quantity of stroma $\left(796.52 \mu \mathrm{m}^{2} \pm 476.83\right)$ than the growing tumors $\left(156.18 \mu \mathrm{m}^{2} \pm 106.02\right)$ $(\mathrm{P}<0.05)$.

TUNEL labeled cells were more abundant during the regression phase (Fig. 3C) than in the growing phase.

All the analyzed samples showed genome fragmentation represented by the classic ladder pattern under the agarose gel electrophoresis. The regressive tumors presented lower integral high molecular DNA than the growing ones. Additionally, the regressive tumors had higher fragmented DNA as evidenced through the intensification of the "ladder pattern" (Fig. 4).

Despite the strong cytoplasmic labeling, only the cells with the labeled nuclei were considered as positive. Under a morphological aspect, the P53 expression was higher in the regressive tumors (Fig. 5A e Fig. 5B). 


\section{Santos et al.}


Figure 1. (A) Transplanted transmissible venereal tumor. (A) Growing phase. Observe the presence of juxtaposed cells, delicate stroma and mitotic figures (white arrows) and small blood vessels (black arrow). (B) Regression phase. Note an anomalous mitosis (arrow) and the presence of a capsule of connective tissue (Shorr, bar $=10 \mu \mathrm{m})$.

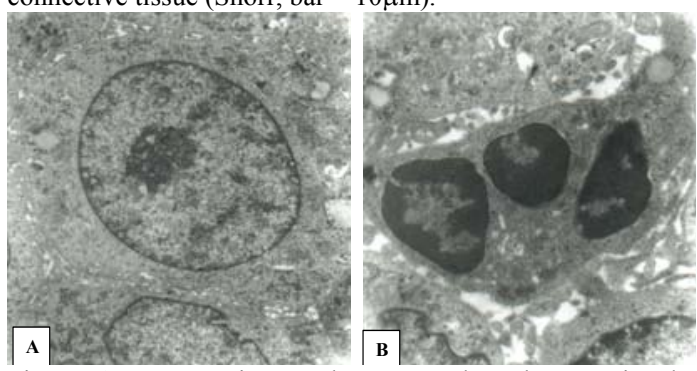

Figure 2. TEM micrography. Transplanted TVT in the regression phase with (A) an oncocyte metabolically active; (B) an apoptotic TVT cell with both cytoplasmic and nuclear chromatin condensation and the nuclear fragmentation $(10,600 \mathrm{X})$.

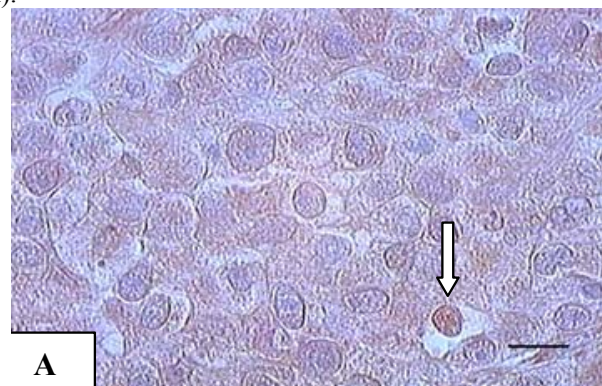

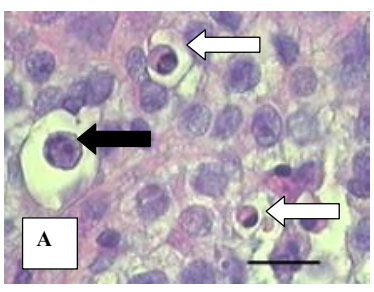
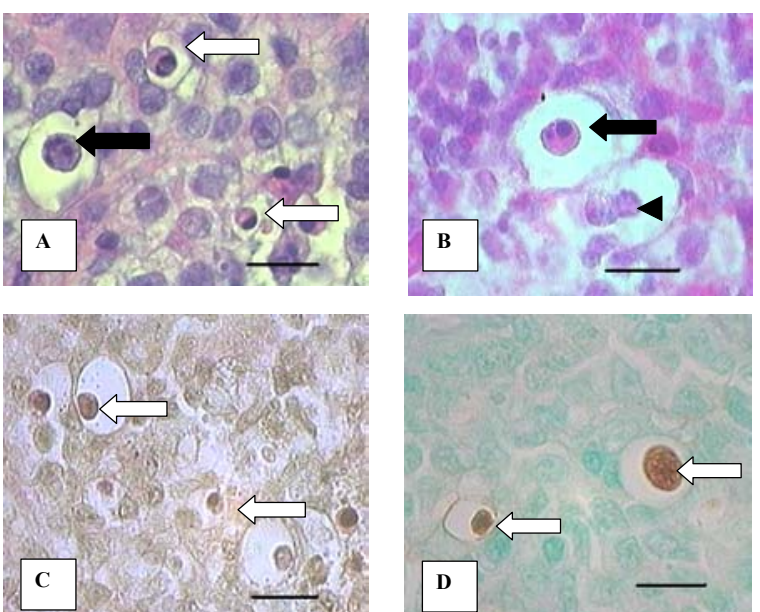

Figure 3. Transplanted TVT in the regression phase. (A) Presence of shrunk isolated apoptotic cells, with a condensed chromatin and fragmented nucleus (black arrow) and apoptotic bodies (white arrow) (A) (HE, bar $=10 \mu \mathrm{m})$. (B) Note a shrunken cell with a fragmented nucleus (black arrow) and a nucleus with a compacted chromatin against the nuclear membrane (arrow head) (MGP, bar $=10 \mu \mathrm{m}$ ). (C) Isolated apoptotic bodies (white arrow) (Van Gieson bar $=10 \mu \mathrm{m}$ ). (D) Presence of a characteristic nuclear labeling by the TUNEL reaction (white arrow) (DAB counterstained by methyl green; bar $=10 \mu \mathrm{m})$.



Figure 4. Typical DNA gel electrophoresis of the DNA extracted from transplanted TVT in the growing phase $(1,2$, 3 and 4) and in the regressive phase (5, 6, 7 and 8). Electrophoresis was performed in a $1.5 \%$ agarose gel, $1 \mathrm{X}$ TE, $1.5 \mathrm{~h}$ at $60 \mathrm{v}$. DNA bands were stained with ethidium bromide $(0.5 \mu \mathrm{g} / \mathrm{ml}) ; \mathrm{m}=$ marker $($ gene ruler $-100 \mathrm{bp}$ DNA ladder, MBI); observe the DNA genome fragmentation yielding bands multiple of $200 \mathrm{bp}$. There is a higher quantity of integral DNA in the growing tumors compared to a higher quantity of fragmented DNA in the regressive tumors.

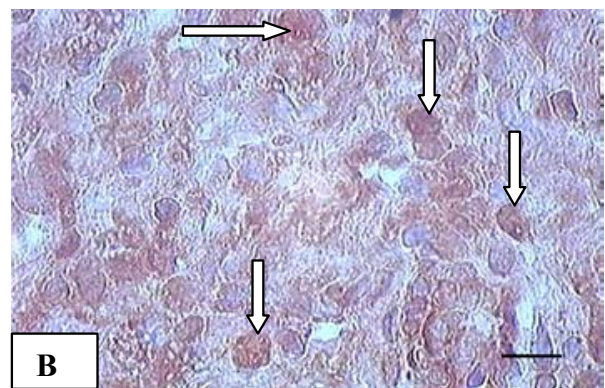

Figure 5. Transplanted transmissible venereal tumor. (A) During the growing phase, presenting a cell (arrow) with nuclear labeling. (B) During the regressive phase evidencing a higher number of cells with nuclear labeling for P53 (arrows). (DAB, bar $=10 \mu \mathrm{m})$. 


\section{DISCUSSION}

The histopathological aspects observed for the naturally acquired and the experimentally transplanted TVTs were in agreement with the (Stewart et al., 1959) and were similar to results of a previous paper on naturally acquired TVT (Santos et al., 2001). The composition and quantity of the stroma observed in the regressive transplanted tumors were more evident than in the growing transplanted TVTs, similarly to genital TVTs (Stewart et al., 1959).

The experimentally transplanted TVT presents a development pattern that includes: progressive growing followed by a brief static phase and regression (Chandler and Yang, 1981). Some authors have associated the TVT regression with cells loosing by necrosis (Cockrill and Beasly, 1975; Hill et al., 1984). In this study, the regression of the TVT seems to involve apoptosis as well. However, apoptosis was also present in the growing tumors, probably due to a moderate ischemia as mentioned by Kerr (1993).

The AI differentiated the growing and the regressive phases of the TVT. As a result, AI was higher in the regressive tumors regardless of the stain (Shorr or MGP). According to Staunton and Gaffney (1998), the detection of a small number of apoptotic cells indicates a great significance in tissue kinetics. In this way, the statistical difference between the AI of the TVT in the growing and regression phases emphasizes the real importance of apoptosis in the spontaneous regression of the TVT.

The occurrence of apoptosis was also demonstrated through the TUNEL reaction (Gavrieli et al., 1992), MGP (Moffitt, 1994) and under the transmission electron microscopy (Kerr, 1993). Besides this, as stated by Wyllie (1981), the internucleosomal fragmentation of the genomic DNA was shown by the agarose gel electrophoresis. It was observed that higher the AI, lower was the concentration of the DNA with high molecular weight and concomitantly a higher concentration of the fragmented DNA.

Equally important, the TVTs in the regression phase presented more P53 labeled cells with an intensified immunolabeling. This datum corroborates with the finding of a higher apoptotic index and a higher degree of genomic fragmentation noticed during the regression of the TVT. The transcription factor P53, the guardian of the genome, is an important protein regulating cell cycle and the integrity of the genome (Lane, 1992). However, the P53 response needs to be thoroughly controlled (Cinelli et al., 1998; Lane, 2004). Accordingly, P53 has a very short half life (20 minutes) and there is a variety of mechanisms that down regulate its activity (Cinelli et al., 1998). Under physiological conditions the P53 protein is expressed at low levels (El-Deiry, 1998) and it is not detected immunocytochemmically. Regardless on what was stimulating apoptosis in the TVT cells; it seems that P53 was involved, considering the higher expression of P53 during the regression phase. In agreement with some authors (Gerschenson and Rotello, 1992; Manning and Patierno, 1996), the p53 gene, through its product, inhibits the tumoral growth and causes the regression of the well established tumors by apoptosis.

As stated by other authors (Bursch et al., 1990; Wright et al., 1994; Liles, 1997; Webb et al., 1997; Wyllie, 1997), apoptosis observed in the regression phase of a neoplasia could be correlated to cellular immune response and the release of cytokines, perforins and granzymes by the cellular infiltrate. Considering that TVT is an allogenic (Cohen, 1978) and antigenic (Rogers, 1997) neoplasia that stimulates an immunological and inflammatory response (Cohen, 1978), these reactions could contribute to trigger apoptosis during TVT regression.

To sum up, apoptosis has an important role in the regression of the experimental TVT and involves a P53-dependent way. Considering its transplantation feasibility, quick growing and spontaneous involution, TVT can be used as an experimental model to study tumor evolution and regression.

\section{REFERENCES}

ALVES, C.M.; VASCONCELOS, A.C.; MARTINS, A.S. et al. Morphometric analysis of the thymus of puppies infected with the Snyder Hill Strain of canine distemper virus. Arq. Bras. Med. Vet. Zootec., v.58, p.472-479, 2006.

ARENDS, M. J.; WYLLIE, H. A. Apoptosis: mechanisms and roles in pathology. Int. Rev. Exper. Pathol., v.32, p. 223254, 1991. 
BATISTA, J.J.; MARTINS, A.S.; MORO, L. et al. Apoptose e expressão de VP2 e GAPDH na infecção precoce pelo vírus da doença infecciosa da bursa de Fabricius em pintos SPF. Arq. Bras. Med. Vet. Zootec., v.59, n.2, p.313-320, 2007.

BATISTA, J.J.; MARTINS, A.S.; MORO, L. et al. Expressão gênica de caspases 3 e 8 em timo e baço de ratas recémdesmamadas e imunossuprimidas por glicocorticóide. Arq. Bras. Med. Vet. Zootec., v.57, p.457-464, 2005.

BURSCH, W.; PAFFE, S.; PUTZ, B. et al. Determination of the length of the histological stages of apoptosis in normal liver and in altered hepatic foci of rats. Carcinogenesis, v.5, p.847-853, 1990 .

CHANDLER, J.P.; YANG, T.J. Canine transmissible venereal sarcoma: distribution of $\mathrm{T}$ and $\mathrm{B}$ lymphocytes in blood, draining lymph nodes and tumors at different stages of growth. Br. J. Cancer, v.44, p.514-521, 1981.

CHU, R.M.; SUN, T.J.; YANG, H. et al. Heat shock proteins in canine transmissible venereal tumor. Vet. Immunol. Immunopathol., v.82, p.9-21, 2001

CINELLI, M.; MAGNELLI, L.; CHIARUGI, V. Redundant down-regulation pathways for p53. Pharmacol. Res., v.37, p.83-85, 1998 .

COCKRILL, J.M.; BEASLEY, J.N. Ultrastructural characteristics of canine transmissible venereal tumor at various stages of growth and regression. Am. J. Vet. Res., v.36, p.677-681, 1975.

COHEN, D. In vitro cell-mediated cytoxicity and antibodydependent cellular cytoxicity to the transmissible venereal tumor of the dog. J. Natl. Cancer Inst., v.64, p.317-321, 1980 .

COHEN, D. The transmissible venereal tumor of the dog- a naturally occurring allograft? A Review. In: WEISS, D.W. (Ed.). Immunological parameters of host-tumor relationships New York: Academic, 1978. v.5, p.14-19

EL-DEIRY, W. S. Regulation of p53 downstream genes. Semin. Cancer Biol., v.8, p.345-357, 1998.

GAVRIELI, Y.; SHERMAN, Y.; BEN-SASSON, S. A. Identification of programmed cell death in situ via specific labeling of nuclear DNA fragmentation. J. Cell Biol., v.119, p.493-501, 1992.

GERSCHENSON, L.E.; ROTELLO, R.J. Apoptosis: a different type of cell death. FASEB J., v.6, p.2450-2455, 1992.

HILL, D.L.; YANG, T.J.; WACHTEL, A. Canine transmissible venereal sarcoma: tumor cell and infiltrating leukocyte ultrastructure at different growth stages. Vet. Pathol., v. 21, p. 39-45, 1984.

KERR, J.F.R. Definition of apoptosis and overview of its incidence. In: LAVIN, M.; WATTERS, D.(Ed). Programmed cell death: the cellular and molecular biology of apoptosis. Switzerland: Harwood Academic, 1993. p.1-15.

KERR, J.F.R.; WYLLIE, A.H.; CURRIE, A.R. Apoptosis: basic biological phenomenon with wide-ranging implications in tissue kinetics. Br. J. Cancer, v.26, p.239-257, 1972.

KOIKE, T.; KUDO, T.; OTOMO, K. et al. Successively transplanted canine transmissible sarcoma. Gann, v.70, p.115-118, 1979.
LANE, D.P. p53, guardian of the genome. Nature, v.358, p.15-16, 1992.

LANE, D. p53 from pathway to therapy. Carcinogenesis, v.25, p.1077-1081, 2004.

LIAO, K.-W.; HUNG, S.-W.; HSIAO, Y.-W. et al. Canine transmissible venereal tumor cell depletion of B lymphocytes: molecule(s) specifically toxic for B cells. Vet. Immunol. Immunopath., v 92, p 149-162, 2003.

LILES, W C. Apoptosis- role in infection and inflammation. Curr. Op. Infect. Dis., v 10, p 165-170, 1997.

LUNA, L.G. Manual of histologic staining methods of the Armed Forces Institute of Pathology. New York: McGrawHill, 1968. 258p.

MANNING, F.C.R.; PATIERNO, S.R. Apoptosis: inhibitor or instigator of carcinogenesis? Cancer Investig., v.14, p.455$465,1996$.

MOFFITT, P.A. Methyl green-pyronin technique for demonstrating cell death in the murine tumour S180. Cell Biol. Intern., v.18, p.677-679, 1994.

PÉREZ, J.; DAY, M.J., MOZOS, E. Immunohistochemical study of the local inflammatory infiltrate in spontaneous canine transmissible venereal tumour at different stages of growth. Vet. Immunol. Immunopathol., v.64, p.133-147, 1998.

ROGERS, K.S. Transmissible venereal tumor. Cont. Educ. Artic., v.19, p.1036-1044, 1997.

SAMBROOK, J.; FRITSCH, D.F.; MANIATIS, T. Molecular cloning: A Laboratory Manual. New York: Cold Spring Harbor Laboratory, 1989.

SAMPAIO, I.B.M. Estatística aplicada à experimentação animal. Belo Horizonte: FEPMVZ, 1998. 221p.

SANTOS, F.G.A.; VASCONCELOS, A.C.; MORO, L. et al. Apoptose no tumor venéreo transmissível canino: características morfológicas e evidenciação bioquímica. Arq. Bras. Med. Vet. Zootec., v.53, p.557-562, 2001.

STAUNTON, M.J.; GAFFNEY, E.F. Apoptosis. Basic concepts and potential significance in human cancer. Arch. Pathol. Lab. Med., v.122, p.310-319, 1998.

STEWART, H.L.; SNELL, K.C.; DUNHAM, L.J. et al. Transplantable and transmissible tumors of animals. Washington, DC: Armed Forces Institute of Pathology, 1959. p.F40-364 - F40-373.

WEBB, S.J.; HARRISON, D.J.; WYLLIE, A.H. Apoptosis of the process and its relevance in disease. Adv. Pharmacol., v.41, p.1-28, 1997.

WRIGHT, S.C.; ZHONG, J.; LARRICK, J.W. Inhibition of apoptosis as a mechanism of tumor promotion. FASEB J., v.8, p.654-660, 1994.

WYLliE, A.H. Apoptosis and carcinogenesis. Eur. J. Cell Biol., v.73, p.189-197, 1997.

WYLLIE, A H. Cell death: a new classification separating apoptosis from necrosis. In: BOWEN, I.D.; LOCKSHIN, R.A. (Eds). Cell death in biology and pathology. New York: Chapman and Hall, 1981. p.9-34. 